кандидат педагогічних наук, доцент

(Вінницький державний педагогічний університет імені Михайла Коцюбинського) blazhk.oleg@ukr.net

ORCID: 0000-0003-2632-9210

\title{
ДОСЛІДНИЦЬКИЙ ПОТЕНЦІАЛ НАУКОВОЇ ШКОЛИ ВЧЕНОГО: СТАНОВЛЕННЯ, РОЗВИТОК, ЗДОБУТКИ
}

У статті розглядається поняття наукової школи вченого з позицій явища культури і наукового осередку закладу вищої освіти. Схарактеризовано склад наукової иколи як цілісного суб' 'кту дослідницької діяльності засновника школи, його послідовників, учнів послідовників. Розкрито основні функиї наукових шкіл. Обгрунтовано, щзо їх дослідницький потенціал становлять дослідження актуальних наукових проблем певного напряму, науково-педагогічна діяльність, підготовка кадрів вищої кваліфікації. Наведено приклад наукового потенциіалу конкретної наукової школи та ї̈ здобутки.

Ключові слова: дослідницький потенціал, засновник, послідовники, наукова школа.

Постановка проблеми у загальному вигляді. За чинним Законом України "Про вищу освіту" важливою місією закладів вищої освіти (університетів, академій, інститутів) $є$ "провадження наукової діяльності шляхом проведення наукових досліджень і забезпечення творчої діяльності учасників освітнього процесу, підготовки наукових кадрів вищої кваліфікації і використання отриманих результатів в освітньому процесі ...забезпечення органічного поєднання в освітньому процесі освітньої, наукової та інноваційної діяльності" [1]. Реалізація такої місії залежить від рівня дослідницької компетентності науковопедагогічних працівників. Вона полягає в наявності і взаємодії знань, умінь, цінностей, необхідних для успішного здійснення дослідницької діяльності й використання іiі результатів в освітньому процесі. Дослідницька компетентність формується не відразу, в ії розвитку простежуються етапи започаткування, становлення, продуктивного розвитку. На етапі продуктивного розвитку дослідницької компетентності у вченого, зазвичай, з'являються послідовники й однодумці його наукового доробку - аспіранти, докторанти, колеги, він плідно здійснює наукову діяльність й ефективно використовує наукові результати у підготовці здобувачів вищої освіти, готує монографії, підручники, посібники. Квінтесенцією цього етапу стає започаткування створення його наукової школи [2].

Для закладів вищої освіти наукова школа - як феномен наукової дійсності має виключно важливе значення, тому потребує теоретичного обгрунтування і практичного втілення.

Аналіз основних досліджень і публікацій із зазначеної проблеми показав, що для педагогіки наукові школи, з одного боку, не є новою проблемою. Так, ще у 1977 році за матеріалами конференції було зроблено видання, в якому окреслено низку актуальних проблем щодо теоретичних аспектів створення i діяльності наукових шкіл [3]. 3 того часу не простежується цілеспрямоване виконання фундаментальних досліджень, присвячених методології дослідження наукових шкіл, теоретичному обгрунтуванню умов і закономірностей їхньої діяльності, в тому числі функцій, умов створення, особливостей розвитку. Час від часу у педагогічних виданнях з'являються окремі статті, що порушують цю проблему. Нашу увагу привернули публікації О. А. Дубасенюк [4], Л. Д. Зеленської [5], на які зроблено посилання в тексті.

Популяризації здобутків вітчизняних вчених і їх наукових шкіл, сприяє серія видань "Науковці України, - еліта держави" видавництва "Логос" (2010, 2012 та ін.).

Мета статті - окреслити основні характеристики і функції наукових шкіл, привернути увагу до ролі наукових шкіл учених, котрі працюють науково-педагогічними працівниками в закладах вищої освіти і роблять вагомий внесок у розвиток науки і суспільства.

Виклад результатів. Матеріалом для дослідження слугували наукові публікації за темою дослідження, Інтернет-сайти закладів вищої освіти і МОН України, результати вивчення вітчизняних практик дослідницької діяльності науково-педагогічних працівників. Були використані емпіричні та загальнологічні методи дослідження. 3 перших переважали вивчення та узагальнення досвіду діяльності наукових шкіл, опитування, бесіди. Сукупність загальнологічних методів представлена аналізом, порівнянням, синтезом, узагальненням. За допомогою зазначених методів з'ясовано трактування феномену наукової школи вченого в педагогіці, склад наукової школи і її функції, вивчено діяльність окремих наукових шкіл закладів вищої освіти в галузі педагогіки. 
За нинішніх умов епоха вчених-одинаків відійшла в минуле. Теперішнє і майбутнє групам однодумців, об'єднаних спільною метою і прогнозованими результатами наукової роботи. Прикладами таких спільнот $є$ наукові школи відділів науково-дослідних установ, кафедри закладів вищої освіти, наукові школи вчених, котрі досягли вагомих наукових результатів і мають послідовників, з якими спільно реалізують наукові ідеї засновника школи.

У нашому дослідженні було зроблено висновок, що феномен наукової школи вченого можна трактувати 3 двох позицій - як явище культури і як осередок наукової думки. Формулюючи визначення наукової школи з першої позиції, ми дотримуємось думки, що наукова школа - це напрям у науці. Практика доводить, що поява цього своєрідного явища пролонгована в часі й не залишається непоміченою в науковому середовищі. "У багатьох університетах доброю традицією є формування й успішна діяльність наукових шкіл, ознакою яких є, зокрема, наявність трьох поколінь дослідників із конкретних наукових напрямів, а саме засновник школи - його послідовники - учні послідовників" [6: 11]. Судячи 3 цієї цитати, до наукової школи входять дослідники різної наукової кваліфікації та різних вікових груп.

У поглядах на наукову школу ми дотримуємось думки, що послідовниками засновника школи необов'язково $є$ його аспіранти, здобувачі і докторанти. Ними можуть бути вчені, котрі поділяють (наслідують) основні ідеї школи і виявили намір долучитись до їх збагачення, поширення і розвитку. Визначальну роль відіграє спільність інтересів. Однак цілком очевидно, що кістяк наукової школи становлять учні вченого.

Як осередок наукової думки, наукова школа є неформальним об'єднанням однодумців, спільнотою, в якій наукові ідеї засновника школи сприймаються і розвиваються послідовниками. Одержані науковою школою результати послідовники та їхні учні поширюють широкому науковому загалу, впроваджують в освітньому процесі.

Щодо однозначності тлумачення наукових шкіл, то в педагогіці вона відсутня. В літературі зустрічаються різні визначення цього терміну, але важливим є те, що в них феномен наукової школи пов'язують 3 незмінним пріоритетом нових відкриттів і розробок лідера школи, узгодженістю дій представників наукової школи. Це дає нам підстави для розгляду наукової школи вченого - як осередку 3 позиції цілісного суб'єкту дослідницької діяльності, колективу однодумців, згуртованих вченим на основі спільних наукових ідей і принципів. Наукові результати школи не є механічною сумою досягнень кожного представника школи, вони значно більші (спрацьовує груповий ефект спільної діяльності).

Л. Д. Зеленська спробувала поєднати у визначенні наукової школи обидві позиції. "В ідеалі наукова школа - це колективний ієрархічний організований розум, що концентрує досвід декількох поколінь. На практиці вона уособлює найяскравіший прояв колективної форми творчості під безпосереднім ідейним і практичним керівництвом визнаного ученого й вчителя, який живить цей колектив науковими ідеями i визначає зміст і методи наукових досліджень" [5].

Наукова діяльність, яку здійснює наукова школа, це "інтелектуальна творча діяльність, спрямована на одержання нових знань та (або) пошук шляхів їх застосування, основними видами якої є фундаментальні та прикладні наукові дослідження" [7].

Унікальність наукової школи вченого, який працює науково-педагогічним працівником, полягає в тому, що вона є дієвою формою організації науки в університетах й виконує такі основні функції:

- продукує ідеї, одержує нові знання, що стосуються як досліджуваної наукової галузі, так i впровадження результатів дослідницької діяльності в освітній процес;

- пропагує наукові досягнення школи в Україні і за їі межами;

- здійснює підготовку докторів філософії й докторів наук;

- налагоджує конструктивні стосунки з представниками інших наукових шкіл;

- $\quad$ дбає про впровадження одержуваних науковою школою результатів;

- $\quad$ береже традиції і примноження цінності, притаманні науковій школі, піклується про наукову зміну.

На даному етапі дослідження ми окреслюємо такі основні принципи життєздатності наукової школи вченого: індивідуальності, наступності, саморозвитку, відкритості до дискусії. Перший принцип полягає в тому, що спільні риси структури і функцій наукових шкіл не уніфікують їх. На думку М. Г. Ярошевського, наукові школи різняться, "по-перше, єдністю навчання творчості і процесу дослідження, по-друге, позицією, якої дотримується одна група вчених по відношенню до інших" [3: 86]. Тобто, наукова школа має свій, відмінний від інших шкіл, стиль діяльності, що залежить від досягнень і наукових поглядів лідера, його досвідченості й особистісних якостей.

Наступність у діяльності наукової школи можна трактувати і як продовження досліджень за напрямом, що склався в діяльності школи, і як появу учнів у послідовників засновника школи.

Важливим моментом у діяльності наукової школи вченого є відкритість до дискусій. Як відомо, завдяки їм з'являється істина.

Саморозвиток - риса сформованої наукової школи, яка не зупиняється на досягнутому, ставить нові завдання, розширює межі експерименту, демонструє відчутний наукових прогрес у конкретній науковій галузі. 
Високий науковий потенціал школа набуває завдяки активній дослідницькій діяльності науковопедагогічних працівників, аспірантів, докторантів, залученню студентів до досліджень за напрямами наукової школи. На зростанні наукового потенціалу школи позначається експертна діяльність ії представників, їхня робота у спеціалізованих вчених радах, опонування дисертацій за науковим напрямом школи тощо.

Як свідчить аналіз вітчизняних практик наукової діяльності закладів вищої освіти, для них на часі питання про офіційне визнання наукових шкіл. Свідченням цього $є$ розроблення в університетах кваліфікаційних ознак, за якими можна здійснювати атестацію наукових спільнот як наукових шкіл, а також затвердження вченими радами закладів вищої освіти положень про наукові школи. Як показав аналіз інформації офіційних Інтернет-сайтів університетів з цього приводу, у спробах визначити статус наукової школи науково-педагогічного працівника заклади вищої освіти віддають перевагу кількісному складу школи й наявності в ній поколінь дослідників; кількості захищених і тих, що готуються до захисту дисертацій за напрямами і тематикою школи; переважаючим групам досліджень (фундаментальні, прикладні, наукові розробки. Тобто, пріоритети різні, бо даються взнаки рівень наукових досягнень закладів вищої освіти, кількість науково-педагогічних працівників й осіб, котрі навчаються в аспірантурі та докторантурі, потужність та досконалість матеріально-технічної бази й освітньо-наукового середовища закладу вищої освіти.

Поняттям властивий розвиток, внаслідок чого вони уточнюються, модифікуються, доповнюються новими характеристиками. Поява поняття "науково-педагогічна школа" свідчить про розвиток поняття "наукова школа" за рахунок означення галузі науки і знань, яким присвячені дослідження вчених [4]. Темпи розвитку наукової школи вченого залежать від рівня дослідницької компетентності ії членів, залучення молодих дослідників, стосунків у самій науковій спільноті, зовнішніх зв'язків. Непересічне значення має особистість засновника школи, його лідерські і загальнолюдські якості, тому, що наукова школа своєрідний організм, де все узгоджено і взаємопов'язано.

Різновекторність дослідницького потенціалу наукової школи полягає в тому, що він реалізується:

- у дослідженнях актуальних наукових проблем за напрямом діяльності школи;

- науково-методичній діяльності;

- підготовці кадрів вищої кваліфікації.

Яскравим прикладом такої багатогранності є діяльність наукової школи Ніни Миколаївни Буринської (1927-2017). почесного академіка НАПН України, доктора педагогічних наук, професора, Заслуженого вчителя України. Науковий потенціал вченого, навколо якого сформувалась наукова школа, забезпечує розв’язання актуальних питань теорії і методики навчання хімії, в тому числі змісту середньої хімічної освіти, диференціації навчання, контролю освітніх результатів, підручникотворення. Наукова школа Н. М. Буринської налічує п'ятнадцять докторів і двадцять п’ять кандидатів педагогічних наук. Ніна Миколаївна була першим і тривалий час єдиним доктором педагогічних наук з теорії і методики навчання хімії в Україні. Формування за роки незалежності потужної наукової школи Н. М. Буринської в галузі теорії і методики навчання хімії стало видатною подією освітньо-наукової дійсності. Школа працює в двох напрямах - розробки змісту і структури хімічної освіти в середній школі й обгрунтування теоретичних основ методичної підготовки майбутніх учителів хімії. Кожен із захищених нею докторів педагогічних наук своїми ідеями і здобутками сприяють розвитку наукової школи Вчителя, а всі разом вони забезпечують загальну середню освіту сучасною компетентнісно орієнтованою методикою навчання хімії, формують нові погляди на зміст хімічної освіти і їі якість. Так, в полі зору досліджень Л. П. Величко перебувають теорія і практика навчання органічної хімії у загальноосвітніх навчальних закладах. Н. І. Лукашкова на високому рівні узагальнення розкриває становлення і розвиток методики навчання хімії в загальноосвітніх школах України. Коло наукових інтересів Ю. А. Романенко стосується теоретикометодичних засад моніторингу результатів навчання хімії в закладах загальної середньої освіти. О. П. Мітрясова своє дослідження присвятила проблемам інтегрованого навчання хімічних дисциплін студентів. В. І. Староста збагатив здобутки наукової школи Н. М. Буринської розробленням теоретичних $\mathrm{i}$ методичних засад навчання школярів складати й розв'язувати завдання 3 хімії: Н. Н. Чайченко всебічно дослідила й обгрунтувала формування у школярів теоретичних знань з основ хімії. Також у полі іiі зору перебувають особливості профільного навчання хімії старшокласників, професійна підготовка.

Разом з іншими послідовниками О. Г. Ярошенко і її учні розвивають і примножують здобутки наукової школи Н. М. Буринської. Великий досвід з поєднання праці вчителя хімії у п’яти київських школах й науково-педагогічного працівника Національного педагогічного університету імені М. П. Драгоманова сприяв проведенню О.Г.Я Ярошенко широкомасштабного десятирічного експерименту. На підставі одержаних результатів вона розробила педагогічні основи групової навчальної діяльності учнів на заняттях 3 хімії, створила для цього різноманітне навчально-методичне забезпечення (підручники, робочі зошити, збірки завдань i вправ, компакт-посібники), втілила у практику розроблений Н. М. Буринською диференційований підхід до використання пізнавальних завдань у навчання хімії, розробивши для цього структуру робочих семінарів з груповою навчальною діяльністю учнів. 
Потужною наукову школу Н .М. Буринської зробила наступність ідей школи у тріаді: засновник школи - послідовники засновника - послідовники послідовників. В цьому плані прикладом може служити наукова діяльність послідовника наукової школи Н. М. Буринської Ольги Ярошенко, чий внесок у розвиток наукового потенціалу школи виріс до створення власної наукової школи із двадцяти двох кандидатів і двох докторів педагогічних наук. Вихованці О.Г.Ярошенко розвивають і поглиблюють теоретичні основи групової навчальної діяльності, яка з роками не втрачає своєї актуальності. Адже формування здатності до роботи в команді, лідерських якостей, уміння співпрацювати у групах гетерогенного складу, розвиток комунікативної компетентності і такої ключової компетентності, як спілкування державною мовою, найкраще відбувається тоді, коли учні чи студенти працюють малими групами. Це знаходить підтвердження у дослідженнях О. А. Блажка, Н. А. Прибори, О. А. Карбованець, І. Г. Косцової та інших вчених, дослідженнями яких керувала О. Г. Ярошенко. Учні О. Г. Ярошенко, А. П. Розсоха, О. А. Блажко мають аспірантів, які або навчаються, або вже захистили дисертації.

Розглянутий приклад є переконливим доказом розвитку наукової школи Н. Буринської і засвідчує той факт, що тріадою засновник школи - його послідовники - учні послідовників склад наукових шкіл не завершується. У наукової школи цілком реальною є поява четвертої сходинки - учні учнів послідовника школи.

Більшість членів наукової школи Н. М. Буринської є науково-педагогічними працівниками ЗВО. Закономірно, що свої наукові досягнення вони впроваджують у підготовку майбутніх учителів, долучаються до досліджень теорії і методики професійної освіти майбутніх учителів хімії, біології, природознавства. Здійснюючи професійну підготовку здобувачів вищої освіти, вони стають творцями і користувачами наукового середовища закладу вищої освіти, налагоджують наукові контакти із зарубіжними колегами.

Науковій школі Н. М. Буринської характерні динамізм, відкритість, налаштованість на розроблення дидактичного й методичного забезпечення навчання хімії у середній та вищій школі на засадах компетентнісного підходу, прагнення розвивати і примножувати ідеї ії засновника.

Науково-освітній напрям у діяльності наукової школи Н. М. Буринської з'явився, коли представники школи, спираючись на ідеї та досвід засновника школи, розпочали створювати підручники і посібники. Створені Н. М. Буринською підручники і посібники стали взірцем для Л. П. Величко, Н. І. Лукашкової, Н. Н. Чайченко, О. Г. Ярошенко з-під пера яких вийшов не один десяток навчальних книг для здобувачів середньої і вищої освіти.

Нині наукова школа Ніни Миколаївни Буринської успішно розвивається, збагачується новими ідеями, в iï складі з'являються нові послідовники. Як осередок наукової думки в галузі теорії і методики навчання хімії, свої ідеї і здобутки школа реалізує на державному рівні під час створення навчальних програм; стандартів середньої і вищої освіти, концепцій диференційованого і профільного навчання учнів нової української школи, участі у всеукраїнських конкурсах "Учитель року (номінація "Хімія")".

Висновки та перспективи подальших досліджень проблеми. Наявність наукових шкіл учених, котрі працюють в університеті науково-педагогічними працівниками, - соціально необхідна потреба, детермінована розвитком науки в університеті. Дієздатний потужній дослідницький потенціал наукової школи формується завдяки ідеям і досягненням лідера школи та його учнів. Згуртованість навколо спільних ідей засновника школи приносить вагомі наукові й науково-освітні результати.

Дослідницький потенціал наукової школи вченого формується і зростає під впливом наукової репутації школи. Здобутками послідовників і їх учнів наукова школа вченого існує, розвивається, здобуває світове визнання. Яскравою спрямованістю на розв'язання актуальних питань теорії і методики навчання хімії характеризується наукова школа Н. М. Буринської, яка налічує у своєму складі три покоління: послідовники ідей засновника школи, учні послідовників, вихованці учнів послідовників.

Дослідження показало, що подальших досліджень і розв'язання потребують питання розроблення загальних методів ідентифікації шкіл, способів обміну і комунікації між науковими школами, які здійснюють дослідження одного наукового напряму; шляхів подолання інформаційного вакууму наукових шкіл, сформованих у закладах вищої освіти; форми донесення інформації про наукові школи та їхні здобутки широкому науковому й освітньому загалу.

\section{СПИСОК ВИКОРИСТАНИХ ДЖЕРЕЛ ТА ЛІТЕРАТУРИ}

1. Про вищу освіту : Закон України № 1556-VII від 1 липня 2014 року [Електронний ресурс]. - Режим доступу : http://zakon3.rada.gov.ua/laws/show/1556-18.

2. Теоретичні основи і технологія професійного розвитку науково-педагогічних працівників університетів в умовах інтеграції вищої освіти і науки : препринт (аналітичні матеріали) ; у 2-х частинах [Електронний ресурс] / Авторський колектив : О. Бульвінська, Н. Дівінська, Н. Дяченко, О. Жабенко, І. Линьова, Ю. Скиба, Г. Чорнойван, О. Ярошенко; за ред. О. Ярошенко. - К. : Інститут вищої освіти НАПН України, 2017. - Ч. 1. - 131 с. - Режим доступу : http://ihed.org.ua/images/biblioteka/Teor_i_tehnol_rozv_np_pracivnikiv_IVO-2017-131p_avtors-kolektiv.pdf.

3. Школы в науке / Под ред. С. Р. Микулинского, М. Г. Ярошевского, Г. Кребера, Г. Штейнера. - М. : Наука,1977. - 524 с. 
4. Дубасенюк О. А. Проблеми розвитку науково-педагогічних шкіл [Електронний ресурс] / О. А. Дубасенюк // Педагогічна газета. - № 10 (218), жовтень 2012. - Режим доступу : http://eprints.zu.edu.ua/12419/1/13.pdf.

5. Зеленська Л. Д. Наукова школа: сутність та етапи становлення [Електронний ресурс] / Л. Д. Зеленська . Режим доступу : http://www.rusnauka.com/10_NPE_2008/Pedagogica/27756.doc.htm.

6. Інноваційні розробки університетів і наукових установ МОН України / Колектив авторів за заг. ред. М. Стріхи та М. Ільченка. - К. : Інститут обдарованої дитини НАПН України, 2017. - 278 с.

7. Про наукову і науково-технічну діяльність : Закон України. № 2269-VIII від 07.03.2018 року [Електронний pecyрc]. - Режим доступу : http://zakon5.rada.gov.ua/laws/show/848-19.

\section{REFERENCES (TRANSLATED \& TRANSLITERATED)}

1. Pro vyshhu osvitu [About Higher Education ] : Zakon Ukraiiny vid 1 lyp. 2014 r. № 1556-VII [Elektronnyi resurs]. Rezhym dostupu : http://zakon3.rada.gov.ua/laws/show/1556-18.

2. Teoretychni osnovy i tekhnologiia profesiinogo rozvytku naukovo-pedaghoghichnykh pratsivnykiv universytetiv $\mathrm{v}$ umovakh integhratsii vyshhoi osvity i nauky [Theoretical Foundations and Technology of Professional Development of Scientific and Pedagogical Workers of Universities in the Conditions of Integration of Higher Education and Science] : preprynt (analitychni materialy) ; u 2-kh chastynakh / Avtors'kyi kolektyv : O. Bulivinsika, N. Divinsika, N. Diachenko, O. Zhabenko, I. Lyniova, Iu. Skyba, Gh. Chornoivan, O. Iaroshenko ; za red. O. Iaroshenko. - K. : Instytut vyshhoii osvity NAPN Ukraiiny, 2017. - Ch. 1. - 131 s. -12 d.a. - Rezhym dostupu: http://ihed.org.ua/images/biblioteka/Teor_i tehnol_rozv_np_pracivnikiv_IVO-2017-131p_avtors-kolektiv.pdf.

3. Shkoly v nauke [Schools in Science] / Pod red. S. R. Mikulinskogo, M. G. Yaroshevskogo, G. Krebera, G. Shteinera. M. : Nauka, 1977. $-524 \mathrm{~s}$.

4. Dubaseniuk O. A Problemy rozvytku naukovo-pedaghoghichnykh shkil [Problems of Development of Scientific and Pedagogical Schools] // Pedaghoghichna hazeta [Pedagogic Newspaper]. - № 10 (218), zhovten' 2012. - Rezhym dostupu : http://eprints.zu.edu.ua/12419/1/13.pdf.

5. Zelensika L. D. Naukova shkola : sutnist' ta etapy stanovlennia [Scientific School: the Essence and Stages of Formation] / L. D Zelensika. - Rezhym dostupu : http://www.rusnauka.com/10_NPE_2008/Pedagogica/27756.doc.htm.

6. Innovatsiini rozrobky universytetiv i naukovykh ustanov MON Ukraiiny [Innovative Developments of Universities and Scientific Institutions of the Ministry of Education and Science of Ukraine] / Kolektyv avtoriv za zagh. red. M. Strikhy ta M. Ilichenka. - K. : Instytut obdarovanoii dytyny NAPN Ukraiiny, 2017. - 278 s.

7. Pro naukovu i naukovo-tekhnichnu diial'nisti [About Scientific and Scientific and Technical Activity] : Zakon Ukraiiny [Elektronnyi resurs]. - Rezhym dostupu : http://zakon5.rada.gov.ua/laws/show/848-19.

\section{Яроченко О. Г., Блажко О. А. Исследовательский потенциал научной иколь ученого: становление, развитие, достижения.}

В статье рассматривается понятие научной школь ученого с позиций явления культуры и научного центра учреждения высшего образования. Охарактеризован состав научной школь как целостного субъекта исследовательской деятельности образованного основателем школь, его последователями, учениками последователей. Обосновано, что их научный потенциал составляют исследования актуальных научных проблем определенного направления, научно-педагогическая деятельность, подготовка кадров высшей квалификащии. Приведен пример научного потенщиала конкретной научной школь и ее достижения.

Ключевые слова: исследовательский потенциил, основатель, последователи, научная школа.

\section{Yaroshenko O. G., Blazhko O. A. Research Potential of Scientific Scholar's School: Creation, Development, Achievements.}

The article deals with the concept of a scholar's scientific school from the point of view of the phenomenon of culture and the scientific center of a higher education institution. The composition of the school as a holistic subject of research activity, created by the founder of the school, his followers, and the disciples of the followers, also was characterized. The basic functions of scientific schools were revealed. It was substantiated that their research potential consists in the research of actual scientific problems of a certain direction, scientific and pedagogical activity, training of personnel of higher qualification.

In this article, there is an example of the scientific potential of a specific school of science and its achievements. The significance of N. M. Burinskaya's scientific school in the development of modern theory and methodology of chemistry training is substantiated. It carried out research in two directions - the development of the content and structure of chemical education in secondary school and the substantiation of the theoretical foundations of methodological training of prospective chemistry teachers. The continuity of the ideas of N. M. Burinsky's school in the triad: the founder of the school - the followers of the founder-followers of followers is characterised.

Key words: research potential, founder, followers, scientific school. 